\title{
An unusual posterior fossa tumour in a young child
}

\author{
John Ross Crawford, ${ }^{1}$ Robert 0 Newbury, ${ }^{2}$ Michael L Levy ${ }^{3}$
}

1 Department of Neurosciences and Pediatrics, University of California San Diego, San Diego, California, USA 2Department of Pathology, University of California San Diego, San Diego, California, USA

${ }^{3}$ Department of Neurosurgery, University of California San Diego, San Diego, California, USA

\section{Correspondence to} Dr John Ross Crawford, jrcrawford@ucsd.edu
To cite: Crawford JR, Newbury RO, Levy ML. BMJ Case Rep Published online: [please include Day Month Year] doi:10.1136/bcr-2013010158

\section{DESCRIPTION}

A 23-month-old previously healthy boy presented to our hospital with a 10-day history of progressive early morning vomiting and sleepiness. Neurological examination revealed an encephalopathic child with impaired upgaze without papilloedema or other focal neurological abnormalities. Emergency MRI demonstrated a large homogeneously enhancing tumour (figure $1 \mathrm{~A}, \mathrm{~B}$ ) that was T2 isointense to grey matter (figure $1 \mathrm{C}$ ), without reduced diffusivity on apparent diffusion coefficient image sequences (figure 1D). Gross total excision of the tumour was obtained (figure $1 \mathrm{E}$ ) and the pathology demonstrated papillary fronds of columnar cells consistent with a diagnosis of choroid plexus papilloma of the fourth ventricle (figure 2). Postoperatively the patient developed fixed leftward gaze preference and worsening hydrocephalus requiring placement of a ventriculoperitoneal shunt.

\section{DISCUSSION}

Choroid plexus papilloma represents $2-6 \%$ of all childhood brain tumours and up to $20 \%$ of tumours in children under 1 year of age. ${ }^{1}$ Usually arising from the lateral ventricles in childhood and the fourth ventricle in adulthood, choroid plexus

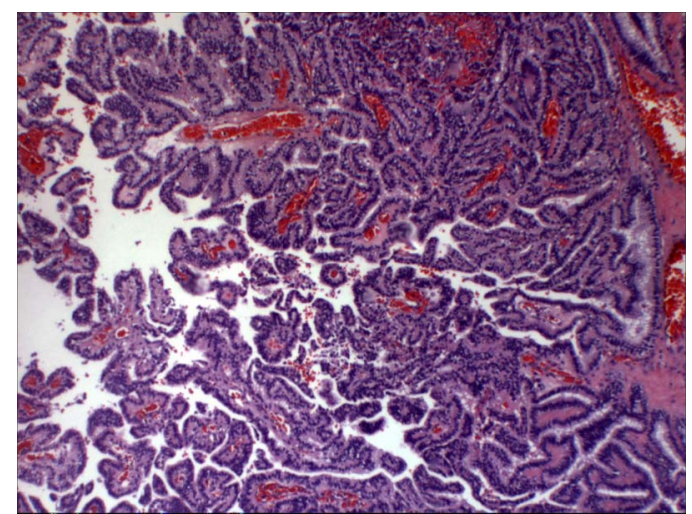

Figure 2 H\&E stained surgical specimen showing papillary fronds with uniform columnar cells lining fibrovascular cores consistent with a diagnosis of choroid plexus papilloma. The cells have oval nuclei with minimal pleomorphism and only rare mitoses without evidence of cytologic atypia or necrosis (40x magnification).

papilloma can be curative following complete neurosurgical correction. ${ }^{2}$ The homogeneous contrast-enhancing features and lack of reduced diffusivity on MRI help distinguish choroid plexus papilloma from more malignant posterior fossa tumours of childhood. Our case highlights the MRI

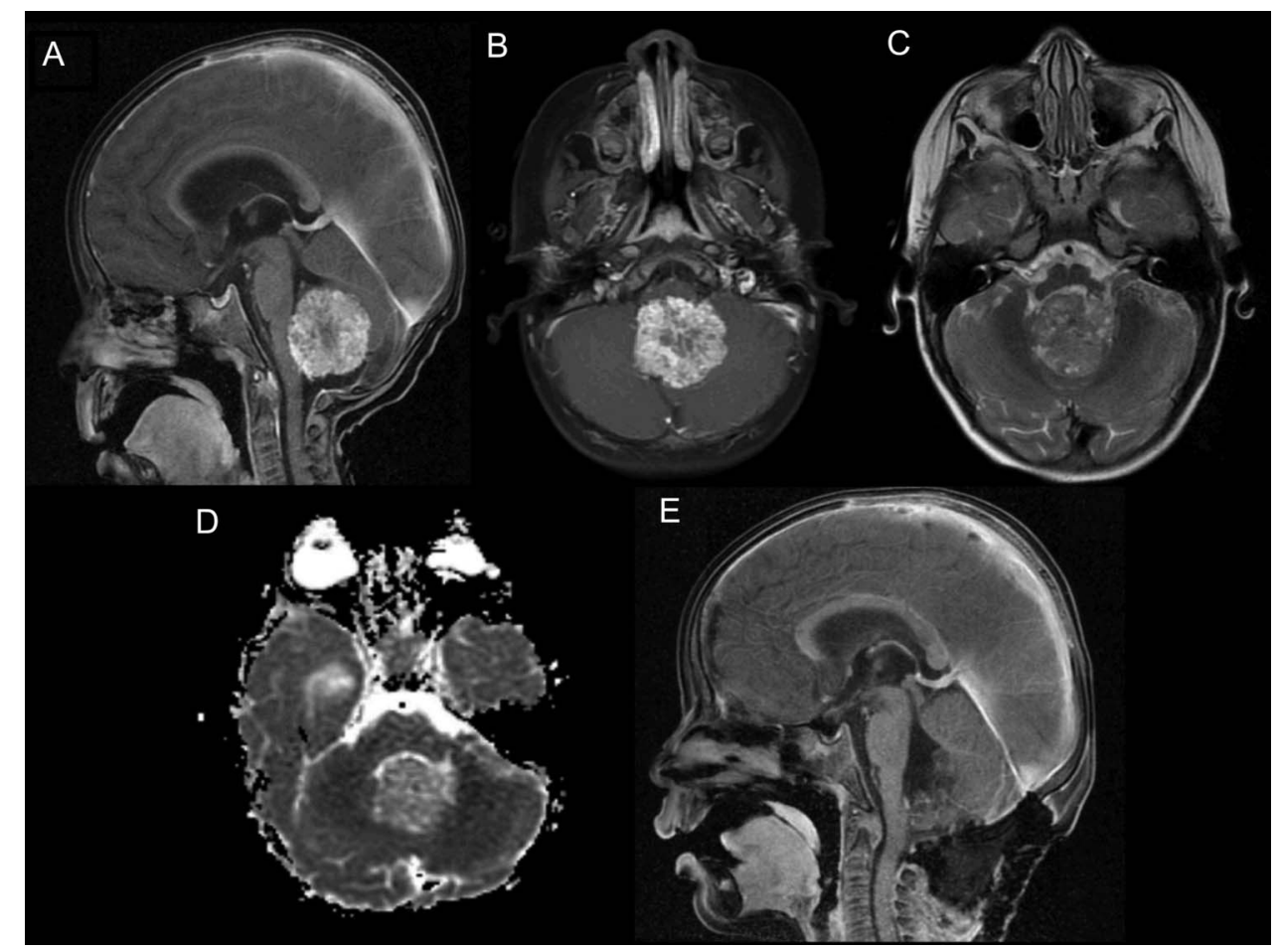

Figure 1 (A, B) Post-gadolinium MRI sequences showing a homogeneous fourth ventricular neoplasm with associated obstructive hydrocephalus. The mass is T2 hypointense compared with grey matter (C) and does not demonstrate reduced diffusivity on apparent diffusion coefficient sequences (D). (E) Postoperative MRI is consistent with a gross total resection. 
features of choroid plexus papilloma of the fourth ventricle and is important to consider in the differential diagnosis of posterior fossa tumours in young children.

\section{Learning points}

- Choroid plexus papilloma is a rare tumour of childhood that may arise anywhere within the ventricular system and cause obstructive hydrocephalus.

- Choroid plexus papilloma of the fourth ventricle is rare in childhood and may radiographically mimic more common homogeneously contrast-enhancing posterior fossa brain tumours.
Contributors JRC, RON, MLL were all equally involved in the conception and design or analysis and interpretation of data, drafting the article or revising it critically for important intellectual content and final approval of the version to be published.

Competing interests None.

Patient consent Obtained.

Provenance and peer review Not commissioned; externally peer reviewed.

\section{REFERENCES}

1 Aguzzi A, Brandner S, Paulus W. Choroid plexus tumours. In: Kleihues P, Cavenee W. eds Pathology and genetics of tumours of the nervous system. Lyon, France: IARC, 2000:84-6.

2 Jaiswal AK, Jaiswal S, Sahu RN, et al. Choroid plexus papilloma in children: diagnostic and surgical considerations. J Pediatr Neurosci 2009;4:10-16.

Copyright 2013 BMJ Publishing Group. All rights reserved. For permission to reuse any of this content visit http://group.bmj.com/group/rights-licensing/permissions.

BMJ Case Report Fellows may re-use this article for personal use and teaching without any further permission.

Become a Fellow of BMJ Case Reports today and you can:

- Submit as many cases as you like

- Enjoy fast sympathetic peer review and rapid publication of accepted articles

- Access all the published articles

- Re-use any of the published material for personal use and teaching without further permission

For information on Institutional Fellowships contact consortiasales@bmjgroup.com

Visit casereports.bmj.com for more articles like this and to become a Fellow 